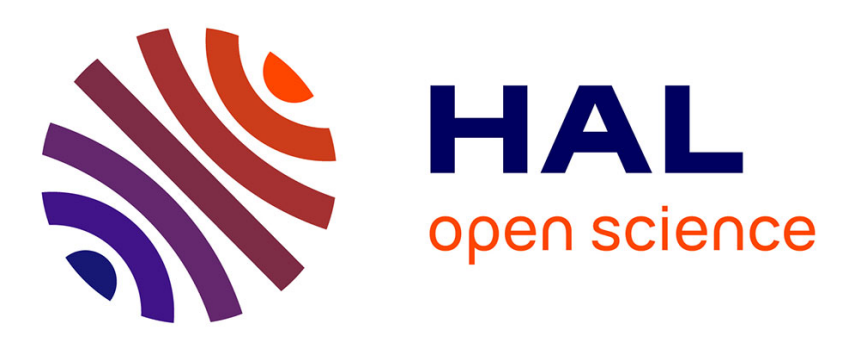

\title{
Light-Controlled Conformational Switch of an Aromatic Oligoamide Foldamer
}

Bappaditya Gole, Brice Kauffmann, Victor Maurizot, Ivan Huc, Yann Ferrand

\section{To cite this version:}

Bappaditya Gole, Brice Kauffmann, Victor Maurizot, Ivan Huc, Yann Ferrand. Light-Controlled Conformational Switch of an Aromatic Oligoamide Foldamer. Angewandte Chemie International Edition, 2019, 58 (24), pp.8063-8067. 10.1002/anie.201902378 . hal-02322262

\section{HAL Id: hal-02322262 \\ https://hal.science/hal-02322262}

Submitted on 21 Oct 2019

HAL is a multi-disciplinary open access archive for the deposit and dissemination of scientific research documents, whether they are published or not. The documents may come from teaching and research institutions in France or abroad, or from public or private research centers.
L'archive ouverte pluridisciplinaire HAL, est destinée au dépôt et à la diffusion de documents scientifiques de niveau recherche, publiés ou non, émanant des établissements d'enseignement et de recherche français ou étrangers, des laboratoires publics ou privés. 


\title{
Light Driven Control of an Aromatic Oligoamide Foldamer Conformational Switch
}

\author{
Bappaditya Gole, ${ }^{[\mathrm{a}]}$ Brice Kauffmann, ${ }^{[\mathrm{b}]}$ Victor Maurizot, ${ }^{[\mathrm{a}]}$ Ivan Huc, ${ }^{*[\mathrm{c}]}$ and Yann Ferrand ${ }^{*[a]}$
}

\begin{abstract}
We have investigated the conformation control of a foldamer switch by light. An aromatic oligoamide sequence composed of a light responsive diazaanthracene-based aromatic $\beta$-sheet flanked by two variable diameter helical segments was prepared. Structural investigations revealed that such oligomers adopt two distinct conformations: a canonical symmetrical conformation with the two helices stacked above and below the sheet, and an unanticipated unsymmetrical conformation in which one helix has flipped to directly stack with the first helix. Photo-irradiation of the foldamer led to the quantitative, and thermally reversible, formation of a single photoproduct resulting from the [4+4] cycloaddition of two diazaanthracenes within the aromatic $\beta$-sheet. NMR and crystallographic studies revealed a parallel (i.e. head-to-head) arrangement of the diazaanthracene photoproduct and a complete conversion to a symmetrical conformation requiring a rearrangement of all unsymmetrical conformers. These results highlight the potential of foldamers with structures more complex that isolated helices for the design of photo-switches showing nontrivial nanometer scale shape changes.
\end{abstract}

Molecular folding constitutes a formidable tool to implement switching, controlled motion and response to external stimuli at the nanometer scale. As best exemplified by the folded conformations of proteins, complex arrays of intramolecular interactions and a hierarchical structure composed of several sheet, turn, loop and helix sub-units, may give rise to sophisticated allosteric behavior; ${ }^{[1]}$ signal transduction across e.g. bilayer membranes through subtle conformational changes mediated by guest binding or by a simple phosphorylation, as in G-protein coupled receptors; ${ }^{[2]}$ or large scale controlled molecular motions coupled to the consumption of chemical energy as performed by kinesin ${ }^{[3]}$ or myosin. ${ }^{[4]}$

Likewise, synthetic foldamers ${ }^{[5]}$ show promise in the design and fabrication of artificial systems endowed with comparable properties and constitute an underexplored approach to artificial molecular switches and motors. ${ }^{[6,7]}$ Until now, most investigations have concerned isolated helically folded oligomers or polymers.

\footnotetext{
[a] Dr. B. Gole, Dr. V. Maurizot, Dr. Y. Ferrand CBMN (UMR5248), Univ. Bordeaux - CNRS - IPB Institut Européen de Chimie et Biologie 2 rue Escarpit, 33600 Pessac (France) E-mail: y.ferrand@iecb.u-bordeaux.fr

[b] Dr. B. Kauffmann

Université de Bordeaux, CNRS, INSERM, UMS3033, Institut Européen de Chimie et Biologie (IECB) 2 rue Robert Escarpit, 33600 Pessac (France)

[c] Prof. I. Huc

Department Pharmazie and E-conversion cluster of excellence Ludwig-Maximilians-Universität

Butenandtstr. 5-13, D-81377 München (Germany)

E-mail: ivan.huc@cup.Imu.de
}

Helices may undergo handedness reversal upon interacting with chiral guests, thus leading to chiral amplification and, eventually, kinetic trapping of chiral helical states, ${ }^{[8]}$ or to the transfer of chiral information from one end of the helix to the other. ${ }^{[9]}$ They may also undergo equilibria between folded and unfolded states triggered by light, ${ }^{[10]}$ and spring-like extensions and contractions mediated by metal ion binding, ${ }^{[11]}$ or a change of redox state. ${ }^{[12]}$ In addition, guest binding to, or release from, a helical host may be associated to single helix-double helix equilibrium, ${ }^{[13]}$ to a light stimulus, ${ }^{[14]}$ or to the ring contraction of a main chain aromatic unit. ${ }^{[15]}$

Beyond isolated helices, one major challenge in foldamer science is the design of abiotic tertiary structures. Early attempts consisted in simply connecting several secondary folded modules with limited interactions between them. ${ }^{[16]}$ Recent progress includes the consistent spatial arrangement of several abiotic helices, ${ }^{[17]}$ as well as aromatic helix and sheet combinations. ${ }^{[18]}$ The increasing size and sophistication of these structures provide opportunities for enhancing the amplitude and complexity of conformational responses to various stimuli. For instance, rotation about a single bond in a large folded object may give rise to a considerable and nontrivial change of molecular shape. Along this line, we now report the reversible, light-induced, switching between different conformations within a helix-sheet-helix aromatic amide foldamer. Specifically, we discovered a foldamer sequence that undergoes unexpected conformation dynamics leading to a non-canonical fold, and that these dynamics can be reversibly controlled by means of an intramolecular photoreaction between two anthracene subunits.

The dimerization of anthracenes under irradiation by light is one of the most studied photochemical reactions. The reversible [4+4] cycloaddition of two anthracene molecules results in a photodimer connected by covalent bonds. ${ }^{[19]}$ For substituted anthracenes, syn/anti and parallel/antiparallel (i.e. head-to-head and head-to-tail) isomeric products may form. Products with opposite dipole orientations are generally favored unless molecular or supramolecular constraints guide the reaction. ${ }^{[20,21]}$ Thus, related 1,8-diazaanthracenes (i.e. pyrido-[3,2-g]quinolines) undergo quantitative antiparallel photodimerization in solution (Figure 1a and S1). ${ }^{[22]}$ Recently, we have shown that, when incorporated in aromatic oligoamide $\beta$-sheet foldamers, 1,8 diazaanthracene units formed parallel stacks favored by a better $\pi-\pi$ overlap (Figure 1b). ${ }^{[18]}$ This observation led us to consider the production of parallel photo-products guided by folding (Figure 1c). Model compound $\mathbf{1}$ was prepared to test this hypothesis (see the supporting information for details, Scheme S1). It comprises two 1,8-diazaanthracenes ${ }^{[23]} \mathrm{A}^{\mathrm{H}}$ separated by a dinitro-diaminobenzene turn ${ }^{24} \mathrm{~T}$. Upon irradiation under anaerobic conditions at $320<\lambda<390 \mathrm{~nm}$ using a 50W lamp and appropriate cutoff filters, ${ }^{1} \mathrm{H}$ NMR monitoring showed the quantitative conversion of $\mathbf{1}$ into a single new product having the same mass in $20 \mathrm{~min}$ (Figure S1). New signals of the former anthracene $\mathrm{H} 10$ and $\mathrm{H} 9$ protons were found as singlets at 5.35 and $5.70 \mathrm{ppm}$ (Figure S1). These 
chemical values are consistent with a [4+4] photoreaction and the lack of $\mathrm{H}^{*}-\mathrm{H} 10^{*}$ scalar coupling indicates that the parallel photoproduct 2 has formed (Figure 1c and S1-S2). ${ }^{[25]}$ Such a quantitative parallel photoreaction guided by folding is remarkable. It reflects not only that the anti-parallel aromatic $\beta$ sheet is disfavored, but also that its conformation is not conducive of a photoreaction (Figure S16). As expected, the reaction was shown to be thermally reversible: in $\mathrm{C}_{2} \mathrm{D}_{2} \mathrm{Cl}_{4}, 2$ was stable at $328 \mathrm{~K}$ but quantitatively converted back into 1 upon heating at $393 \mathrm{~K}$ for 15h (Figure S3-S4).

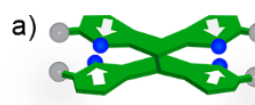

"anti-parallel" photodimer

d)<smiles>[R]c1cc(C(C)=O)nc2c(NC)cccc12</smiles>

Q<smiles>CNc1cc(NC)c(Nc2cc(C)c([N+](=O)[O-])c(C)c2)c(Nc2c(C)cc(NC)cc2[N+](=O)[O-])c1</smiles>

T

e)

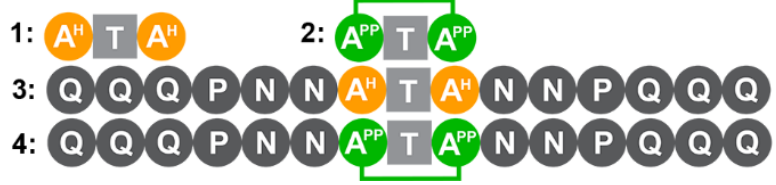

Figure 1. Cartoon representations of: (a) an antiparallel diazaanthracene photodimer; (b) a parallel arrangement of strands in a diazaanthracene $\beta$-sheet and (c) a parallel diazaanthracene photo-product in an aromatic $\beta$-sheet. In $(a, b, c)$ white arrows indicate local dipole orientation and blue spheres indicate nitrogen atoms. (d) Color coded formula and associated letters corresponding to amino acid, diamine, and diacid monomers. (e) Oligoamide sequences 1-4 Note that $\mathbf{2}$ and $\mathbf{4}$ are the photo-products of $\mathbf{1}$ and $\mathbf{3}$, respectively. The terminal $A^{H}$ and $Q$ units of these sequences have a methyl ester group and an 8-nitro group (instead of an 8-amino function), respectively.

We then planned to test this photoreaction within a larger foldamer structure. Sequence 3 comprising two conical $\mathrm{Q}_{3} \mathrm{PN}_{2}$ helical hexameric segments attached on both sides of a central $\mathrm{A}^{\mathrm{H}} \mathrm{TA} \mathrm{A}^{\mathrm{H}}$ sheet was designed and synthesized (Scheme S2-S3). We have previously observed that a related sequence having a longer, three-stranded ATATA sheet folds in a canonical manner with its two helical segments stacked on each side of the central aromatic $\beta$-sheet. ${ }^{[18]}$ With only two strands, as in $\mathbf{3}$, a $\beta$-sheet is expected to mediate a helix handedness reversal leading to a plane symmetrical conformation noted $(M, P)$-s3 (see energy minimized models in Figure $2 \mathrm{e}$ and $\mathrm{S} 17)$. In line with earlier observations, ${ }^{[18]}$ the ${ }^{1} \mathrm{H}$ NMR spectrum of 3 in $d_{6}$-acetone shows one set of sharp lines whose multiplicity is consistent with an overall symmetrical $(M, P)$-s3 structure (Figures $2 \mathrm{a}$ and $\mathrm{S6}$ ). However, the ${ }^{1} \mathrm{H}$ NMR spectrum of 3 in $\mathrm{CDCl}_{3}$ revealed a more complex situation. The symmetrical species that prevails in $d_{6-}$ acetone is also present but a second set of broad signals indicates coexistence with an other species in slow exchange on the NMR time scale (Figure 2b). Upon cooling in $\mathrm{CDCl}_{3}$ down to $233 \mathrm{~K}$, the proportion of this species increased to exceed $50 \%$ and signals remained somewhat broad (Figure $2 \mathrm{c}$ and S7-S8). In $\mathrm{CD}_{2} \mathrm{Cl}_{2}$, the signals sharpened at $243 \mathrm{~K}$ and below (Figure $\mathrm{S} 10$ ) and revealed a number of amide resonances compatible with a dissymmetrical structure (Figure 2d and S10).

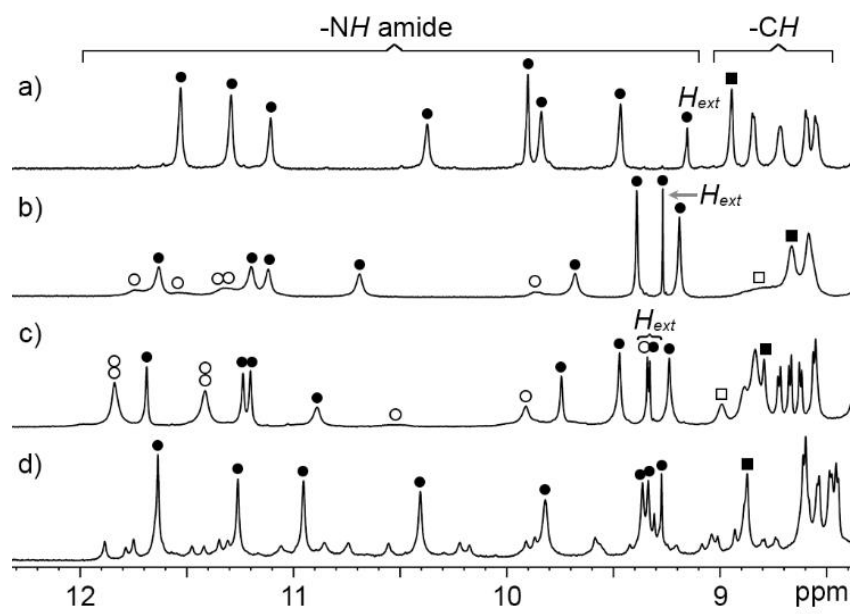

e)
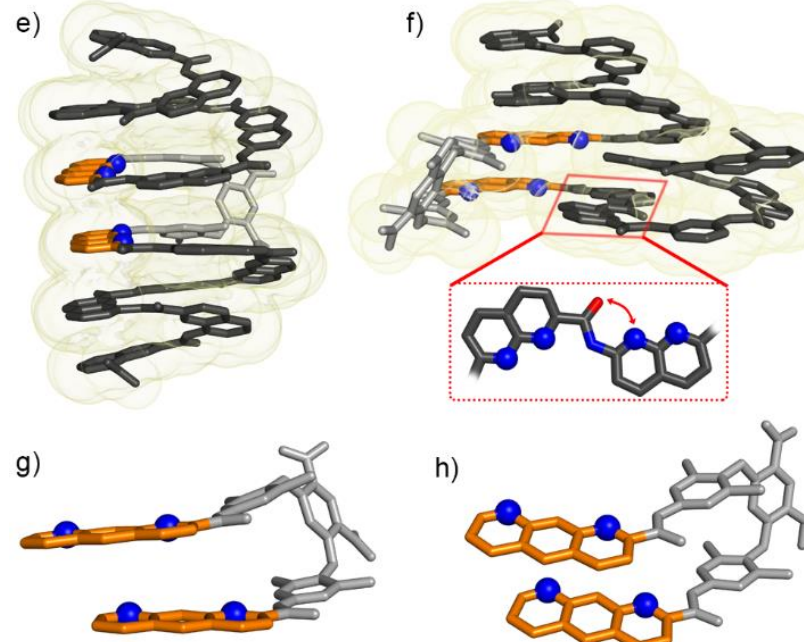

h)

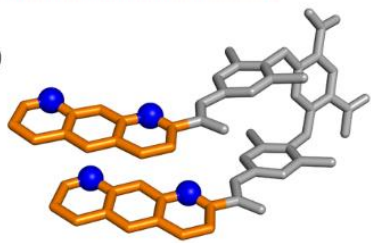

Figure 2. Part of the $700 \mathrm{MHz}{ }^{1} \mathrm{H}$ NMR spectra of $3(1 \mathrm{mM})$ at: (a) $298 \mathrm{~K}$ in $d_{6}$ acetone; (b) $298 \mathrm{~K}$ in $\mathrm{CDCl}_{3}$; (c) $233 \mathrm{~K}$ in $\mathrm{CDCl}_{3}$ and (d) $213 \mathrm{~K}$ in $\mathrm{CD}_{2} \mathrm{Cl}_{2}$. Signals assigned to symmetrical $(M, P)-s \mathbf{3}$ and unsymmetrical $(M, P)-U \mathbf{3}$ are marked with black ( $\bullet$ ) and empty (o) circles, respectively. The black and empty squares denote the amino protons of the turn unit for $(M, P)-s \mathbf{3}$ and $(M, P)-U \mathbf{3}$ respectively. (e) Side view of the energy-minimized molecular model using Merck Molecular Force Field static (MMFFs) of plane symmetrical $(M, P)$-s3. (f) Front view of the structure in the solid state of unsymmetrical $(M, P)$-u3. The zoom highlights the rotation of a helical segment about an amide-naphthyridine bond. A red double-headed arrow denotes a local electrostatic repulsion. $(\mathrm{g}, \mathrm{h})$ Zoom on the diazaanthracene $\beta$-sheet turn unit in $(M, P)$-s3 (from e) and $(M, P)$ U3 (from f), respectively. The model and X-ray structures are shown in tube representation with color coded monomers as in Fig. 1. Blue balls indicate endocyclic nitrogens atoms. Transparent yellow isosurfaces represent the volume of the foldamer. Hydrogen atoms, side chains and solvent molecules are not shown for clarity.

Solid state investigations shed light on the conformational behavior of 3 . X-ray quality single crystals were grown by slow diffusion of hexane into a chloroform solution. The solid-state structure revealed an unanticipated unsymmetrical conformation in which a helical domain has undergone a large flip to stack underneath the other helix (Figure 2e), and to which the dissymmetrical species observed in solution may tentatively be assigned. This conformer, which we named $U \mathbf{3}$, is accessible from $(M, P)$-s3 through a $180^{\circ}$ rotation about a single aryl-amide bond between two $\mathrm{N}$ units. Apart from that, both helical segments and the parallel aromatic $\beta$-sheet fold as expected. The single bond 
rotation results in a repulsive electrostatic interaction between an amide oxygen atom and an adjacent naphthyridine endocyclic nitrogen atom (Figure 2e). This is apparently compensated by favorable contacts including through the antiparallel stacking of the second quinoline of one helix and a naphthyridine of the other helix and through the filling of the cavity of one helix by an isobutoxy side chain of the other helix (Figure S14). These contacts would not occur for $\beta$-sheets with three or more aromatic strands, hence the absence of unsymmetrical conformer for longer parent sequences. ${ }^{[18]}$ Conformation $\mathbf{Z}_{\mathbf{3}}$ in principle exists as a mixture of two degenerate $(M, P)$ and $(P, M)$ states. The mechanism of their interconversion is unclear, and in particular whether or not it must transit through $s 3$ (equilibria $1 \& 2$ in Figure 3).
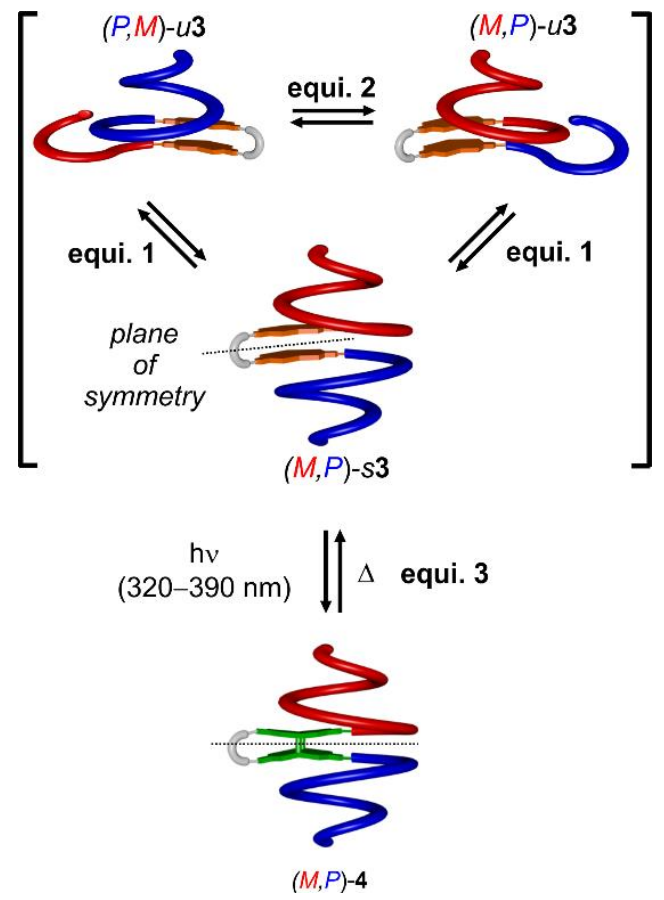

Figure 3. Schematic representation of the equilibria involved in the switching process. Equilibria 1 and 2 do not require helix handedness inversion. Yet the ensemble of $u \mathbf{3}$ and $s \mathbf{3}$ species is at slow equilibrium with another mirror-imaged (thus degenerate) ensemble obtained through handedness reversal of both helical segments. The thermally reversible photoreaction of the two parallel $\mathrm{A}^{\mathrm{H}}$ units (equi. 3 ) locks the conformation in a plane symmetrical state. $P$ and $M$ helices are shown as blue and red tubes, respectively. The diazaanthracene $\beta$ sheet and its photo-product are color-coded in orange/grey and green/grey, respectively.

In both the crystal structure of $\mathcal{3} 3$ and the energy minimized model of $s 3$, the two $\mathrm{A}^{\mathrm{H}}$ units have a parallel orientation but are significantly offset (Figure $2 \mathrm{f}, \mathrm{g}$ ) and not ideally preorganized for a [4+4] cycloaddition. Photoirradiation of 3 in $\mathrm{CDCl}_{3}$ was nonetheless performed. Thus, a $1 \mathrm{~mm}$ solution was irradiated under an argon atmosphere and a photoreaction took place, albeit at a slower rate than with 1 . As followed by ${ }^{1} \mathrm{H}$ NMR, $80 \%$ of the starting oligomer $\mathbf{3}$ was converted into its photoproduct $\mathbf{4}$ after $1 \mathrm{~h}$ of irradiation (Figure 4b). Complete conversion was reached within $4 \mathrm{~h}$ (Figure 4c,e). The slower kinetics may be assigned to the not-ideal conformation mentioned above and to favorable interactions within $\mathbf{U} \mathbf{3}$ and $s \mathbf{3}$ that must be disrupted for the reaction to take place. The parallel arrangement of the photoproduct was again ascertained by the emergence of two singlets at 4.8 and $5.5 \mathrm{ppm}$ assigned to $\mathrm{H} 10^{*}$ and $\mathrm{H}^{*}$, respectively. In addition, the ${ }^{1} \mathrm{H}$ NMR spectrum of 4 shows a single set of signals and indicates a symmetrical structure.

The symmetrical conformation with a $P$ and an $M$ helices, and the parallel arrangement of the photoproduct were confirmed by a solid state structure of 4 . Crystals grew upon slowly diffusing methanol in a chloroform solution. The structure was solved in the $\mathrm{P}-1$ space group and revealed that the helices remain above and below the butterfly-shaped photoreacted $\beta$-sheet in a canonical structure even though proper stacking onto the $A^{H}$ units is no longer possible. Thus, the photoreacted turn is fully embedded inbetween the two helices, with $\mathrm{H}^{*}$ protons pointing towards the concave side of the sheet whereas $\mathrm{H} 10^{*}$ protons point towards to convex side of the sheet (Figure $4 \mathrm{f}-\mathrm{h}$ ).
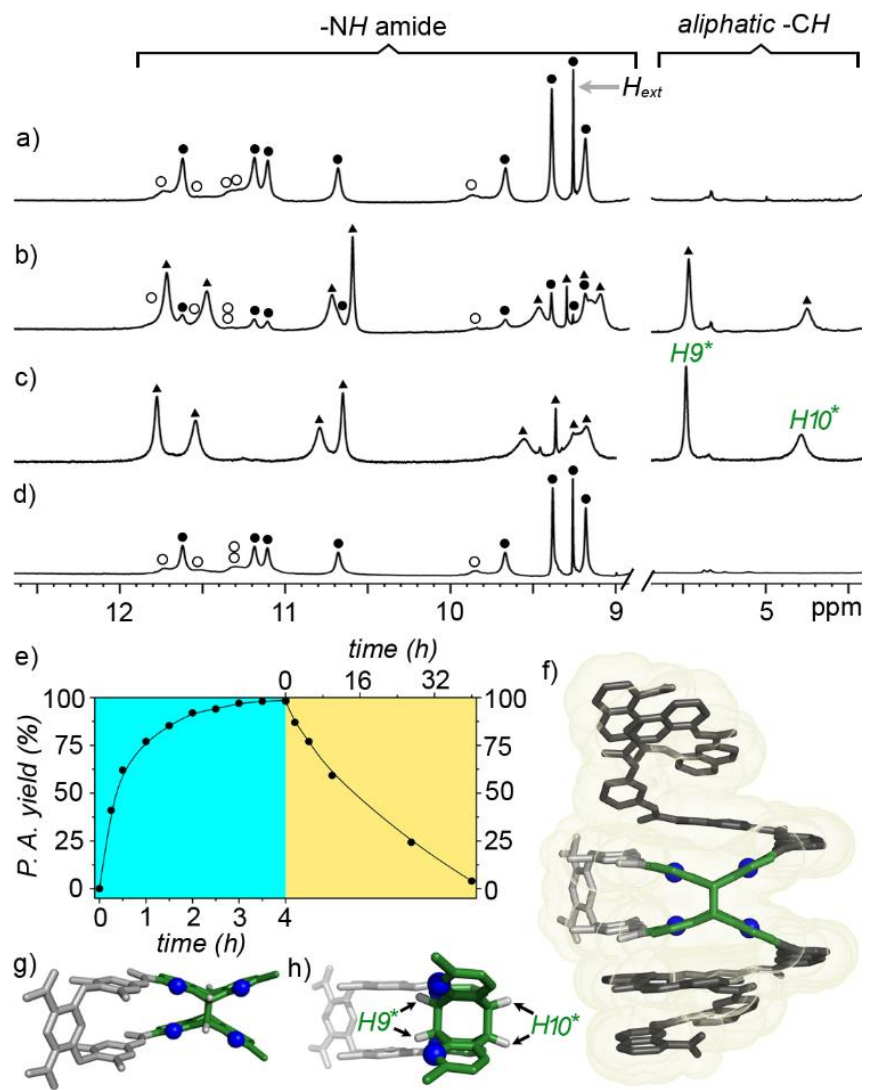

Figure 4. Part of the $700 \mathrm{MHz}{ }^{1} \mathrm{H}$ NMR spectra of at $298 \mathrm{~K}$ of $3\left(1 \mathrm{mM}\right.$ in $\left.\mathrm{CDCl}_{3}\right)$ under photoirradiation after (a) $0 \mathrm{~min}$; (b) $60 \mathrm{~min}$.; (c) $4 \mathrm{~h}$. (d) Evolution after incubating sample (c) at $328 \mathrm{~K}$ for $40 \mathrm{~h}$. Signals of $s 3$ and $u 3$ are denoted with black $(\bullet)$ and white (o) circles, respectively. Black triangles indicate signals of photo-product 4. (e) Kinetic monitoring ( ${ }^{1} \mathrm{H}$ NMR) of: (left) the photoreaction of 3 yielding $\mathbf{4}$ and (right) the thermolysis of $\mathbf{4}$ back into 3 . f) Crystal structure of 4 . $(\mathrm{g}, \mathrm{h})$ Front and side views of the photoreacted $\beta$-sheet highlighting the parallel arrangement. The structure is shown in tube representation and the monomers are color coded as in Fig. 1. Blue balls denote endocyclic nitrogen atoms. Side chains, solvent molecules and hydrogen atoms are not shown for clarity.

Starting from the equilibrating mixture of $u 3$ and $s 3$ conformers, light thus allows one to lock the molecule in a planesymmetrical conformation that has been expanded by the photoreaction, and thus to remove unsymmetrical conformers (Figure 3), as when longer sheets are present. The reaction between the two $A^{H}$ units is selective: cross-reaction with other heterocycles in the structure is avoided. ${ }^{[26]}$ Furthermore, the photoproduct can be thermally reverted to the mixture of $u 3$ and 
s3. Heating 4 in $\mathrm{CDCl}_{3}$ at $328 \mathrm{~K}$ led to $\sim 50 \%$ of conversion after 16 hours. Quantitative recovery of 3 required almost two days. One should note that, despite being slow, this reverse reaction is perfectly clean and anyway much faster than for photo-product 2 which is stable at this temperature. The lower stability of $\mathbf{4}$ possibly reflects a higher strain imposed by folding.

In summary, we have discovered an unanticipated unsymmetrical conformer in helix-sheet-helix foldamers, and found that the quantitative parallel photoreaction of diazaanthracenes within aromatic $\beta$-sheets exclusively and reversibly produces symmetrical conformers. The cleanness of the photoreaction suggests that it could be implemented multiple times within a given aromatic foldamer sequence, thus leading to a global stiffening and length extension of the molecule, or that it could be reliably used to control guest binding and release. Efforts toward these objectives are currently in progress and will be reported in due course.

\section{Acknowledgements}

This work was supported by the post-doc program of the Excellence Initiative of Bordeaux University (B.G.). This work has benefited from the facilities and expertise of the Biophysical and Structural Chemistry platform (BPCS) at IECB, CNRS UMS3033, Inserm US001, and Bordeaux University.

Keywords: foldamer $\cdot$ photochemistry $\cdot$ molecular switch • aromatic oligoamide $\cdot \mathrm{X}$-ray crystallography

[] M. F. Perutz, Nature 1972, 237, 495-499.

[2] B. T. DeVree, J. P. Mahoney, G. A. Velez-Ruiz, G. F. Rasmussen Soren, A. J. Kuszak, E., Edwald, J.-J. Fung, A. Manglik, M. Masureel, Y. Du, R A. Matt, E. Pardon, J. Steyaert, B. K. Kobilka, R. K. Sunahara Nature 2016, 535, 182-186

[3] K. Svoboda, C. F. Schmidt, B. J. Schnapp, S. M. Block, Nature 1993, $365,721-727$

$\left.{ }^{4}\right] \quad$ T. Sakamoto, M. R. Webb, E. Forgacs, H. D. White, J. R. Sellers, Nature 2008, 455, 128-132

G. Guichard, I. Huc, Chem. Commun. 2011, 47, 5933-5941.

[6] For reviews see: (a) Molecular Switches (Eds.: B. L. Feringa, W. R. Browne), $2^{\text {nd }}$ ed., Wiley-VCH, Weinheim, 2011. (b) New Frontiers in Photochromism (Eds.: M. Irie, Y. Yokoyama, T. Seki) Springer, Japan, 2013. (c) T. van Leeuwen, A. S. Lubbe, P. Štacko, S. J. Wezenberg, B. L. Feringa, Nat. Rev. Chem. 2017, 1, 0096.

[7] (a) D. Roke, C. Stuckhardt, W. Danowski, S. J. Wezenberg, B. L. Feringa, Angew. Chem., Int. Ed. 2018, 57, 10515-10519; Angew.Chem. 2018,130,10675-10679. (b) R. Mogaki, K. Okuro, T. Aida, J. Am. Chem. Soc. 2017, 139, 10072-10078. (c) J. Gurke, S. Budzak, B. M Schmidt, D. Jacquemin, S. Hecht, Angew. Chem., Int. Ed. 2018, 57, 4797-4801; Angew.Chem. 2018,130, 4888-4893. (d) S. Fredrich, R Gostl, M. Herder, L. Grubert, S. Hecht, Angew. Chem., Int. Ed. 2016, 55, 1208-1212; Angew.Chem. 2016,128,1226-1230. (e) I. Aprahamian, Chem. Commun. 2017, 53, 6674-6684. (f) H. Qian, S. Pramanik, I. Aprahamian, J. Am. Chem. Soc. 2017, 139, 9140-9143. (g) K. M. Chan, D. K. Kolmel, S. Wang, E. T. Kool, Angew. Chem., Int. Ed. 2017, 56, 6497-6501; Angew.Chem. 2017,129, 6597-6601. (h) J. R. Hemmer, S. O. Poelma, N. Treat, Z. A. Page, N. D. Dolinski, Y. J. Diaz, W. Tomlinson, K. D. Clark, J. P. Hooper, C. Hawker, J. Read de Alaniz, J. Am. Chem. Soc. 2016, 138, 13960-13966. (i) D. Zhao, T. van Leeuwen, J. Cheng, B. L. Feringa, Nat. Chem. 2017, 9, 250-256.

${ }^{8}$ ] T. Miyagawa, A. Furuko, K. Maeda, K. Katagiri, Y. Furusho, E. Yashima Am. Chem. Soc. 2005, 127, 5018-5019.

[9] (a) D. Mazzier, M. Crisma, M. De Poli, G. Marafon, C. Peggion, J. Clayden, A. Moretto, J. Am. Chem. Soc. 2016, 138, 8007-8018. (b) F
G. A. Lister, B. A. F. Le Bailly, S. J. Webb, J. Clayden, Nat. Chem. 2017, 9, 420-425.

$\left[{ }^{10}\right]$ (a) C. Tie, J. C. Gallucci, J. R. Parquette, J. Am. Chem. Soc. 2006, 128, 1162-1171. (b) Z. Yu, S. Hecht, Angew. Chem., Int. Ed. 2011, 50, 16401643.

[11] N. Ousaka, K. Shimizu, Y. Suzuki, T. Iwata, M. Itakura, D. Taura, H. lida, Y. Furusho, T. Mori, E. Yashima, J. Am. Chem. Soc. 2018, 140, 1702717039.

$\left.{ }^{12}\right]$ E. Ohta , H. Sato, S. Ando, A. Kosaka, T. Fukushima, D. Hashizume, M Yamasaki, K. Hasegawa, A. Muraoka, H. Ushiyama, K. Yamashita, T. Aida, Nature Chem. 2011, 68-73.

[13] (a) F. C. Parks, Y. Liu, S. Debnath, S. R. Stutsman, K. Raghavachari, A. H. Flood, J. Am. Chem. Soc. 2018, 140, 17711-17723. (b) Y. Hua, Y Liu, C.-H. Chen, A. H. Flood, J. Am. Chem. Soc. 2013, 135, 1440114412.

[4] Y. Hua, A. H. Flood, J. Am. Chem. Soc. 2010, 132, 12838-12840.

[5] G. Lautrette, C. Aube, Y. Ferrand, M. Pipelier, V. Blot, C. Thobie, B. Kauffmann, D. Dubreuil, I. Huc Chem. Eur. J. 2014, 20, 1547-1553.

[6] (a) N. Delsuc, M. Hutin, V. E. Campbell, B. Kauffmann, J. R. Nitschke, I. Huc, Eur. J. Chem. 2008, 14, 7140-7143. (b) N. Delsuc, S. Massip, J.M. Léger, B. Kauffmann and I. Huc, J. Am. Chem. Soc. 2011, 133, 31653172. (c) W. Ichinose, J. Ito and M. Yamaguchi, Angew. Chem. Int. Ed. 2013, 52, 5290-5294. (d) C. Tsiamantas, X. de Hatten, C. Douat, B. Kauffmann, V. Maurizot, H. Ihara, M. Takafuji, N. Metzler-Nolte, I. Huc, Angew. Chem. Int. Ed 2016, 55, 6848-6852. (e) H.-Y. Hu, J.-F. Xiang, Y. Yang, C.-F. Chen, Org. Lett. 2008, 10, 69-72

[7] S. De, B. Chi, T. Granier, T. Qi, V. Maurizot, I. Huc, Nature Chem. 2017, 10, 51-57.

[8] A. Lamouroux, L. Sebaoun, B. Wicher, B. Kauffmann, Y. Ferrand, V. Maurizot, I. Huc, J. Am. Chem. Soc. 2017, 139, 14668-14675.

[9] (a) H. D. Becker, Chem. Rev. 1993, 93, 145-172.

$\left.{ }^{20}\right]$ For reviews see: (a) H. Bouas-Laurent, A. Castellan, J.-P. Desvergne, R. Lapouyade, Chem. Soc. Rev. 2000, 29, 43-55. (b) H. Bouas-Laurent A. Castellan, J.-P. Desvergne, R. Lapouyade, Chem. Soc. Rev. 2001 30, 248-263.

[21] (a) J. Tanabe, D. Taura, N. Ousaka, E. Yashima, J. Am. Chem. Soc 2017, 139, 7388-7398. (b) P. Kissel, D. J. Murray, W. J. Wulftange, V. J. Catalano, B. T. King, Nat. Chem. 2014, 6, 774-778. (c) Y. Kawanami, S Y. Katsumata, M. Nishijima, G. Fukuhara, K. Asano, T. Suzuki, C. Yang, A. Nakamura, T. Mori, Y. Inoue, J. Am. Chem. Soc. 2016, 138, $12187-$ 12201. (d) M. J. Kory, M. Worle, T. Weber, P. Payamyar, S. W. van de Poll, J. Dshemuchadse, N. Trapp, A. D. Schluter, Nat. Chem. 2014, 6 779-784. (e) A. Nakamura, Y. Inoue, J. Am. Chem. Soc. 2003, 125, 966972. (f) J. Yao, Z. Yan, J. Ji, W. Wu, C. Yang, M. Nishijima, G. Fukuhara T. Mori, Y. Inoue, J. Am. Chem. Soc. 2014, 136, 6916-6919. (g) A. V. Lunchev, S. A. Morris, R. Ganguly, A. C. Grimsdale, Chem. Eur. J. 2019, 25, DOI: 10.1002/chem.201805466.

[22] (a) H. Ihmels, Christian J. Mohrschladt, A. Schmitt, M. Bressanini, D. Leusser, D. Stalke, Eur. J. Org. Chem. 2002, 2002, 2624-2632. (b) D Jouvenot, E. C. Glazer, Y. Tor, Org. Lett. 2006, 8, 1987-1990. (c) E. Berni, C. Dolain, B. Kauffmann, J.-M. Léger, C. Zhan, I. Huc, J. Org. Chem. 2008, 73, 2687-2694. (d) M. Li, A. D. Schluter, J. Sakamoto, J. Am. Chem. Soc. 2012, 134, 11721-11725. (e) P. Payamyar, M. Servalli, T. Hungerland, A. P. Schutz, Z. Zheng, A. Borgschulte, A. D. Schluter, Macromol. Rapid Commun. 2015, 36, 151-158.

$\left.{ }^{23}\right] \quad$ M. L. Singleton, N. Castellucci, S. Massip, B. Kauffmann, Y. Ferrand, I. Huc, J. Org. Chem. 2014, 79, 2115-2122.

$\left.{ }^{24}\right] \quad$ L. Sebaoun, V. Maurizot, T. Granier, B. Kauffmann, I. Huc, J. Am. Chem. Soc. 2014, 136, 2168-2174. (b) L. Sebaoun, B. Kauffmann, T. Delclos, V. Maurizot, I. Huc, Org. Lett. 2014, 16, 2326-2329.

$\left.{ }^{25}\right] \quad$ note: in the antiparallel photoproduct, these protons would appear as two doublets as the result of ${ }^{\beta}$ scalar coupling.

$\left.{ }^{26}\right] \quad$ H. Masu, I. Mizutani, T. Kato, I. Azumaya, K. Yamaguchi, K. Kishikawa S. Kohmoto, J. Org. Chem. 2006, 71, 8037-8044. 
